\title{
弱光下生长的葡萄叶片蒸腾速率和 气孔结构的变化
}

战吉 $\square$ 黄卫东* 王秀芹 王利军

(中国农业大学食品科学与营养工程学院, 北京 100094)

\begin{abstract}
摘 要 植物能够对生长环境产生生态适应性, 这种适应性可从气孔导度、光合速率、水分利用效率等生态指标上 反映出来。为了研究葡萄蒸腾特性对弱光环境的适应性变化, 本试验以 ‘京玉” 葡萄幼苗 (Vitis vinefera cv. Jingyu) 为 试验材料, 通过遮光处理 (2 个处理, 分别遮光 $65 \%$ 和 $85 \%$ ) 营造弱光环境, 测定了在弱光环境下生长的葡萄叶片蒸 腾速率、气孔导度、水分利用效率对光照强度的响应, 同时用扫描电镜技术观察了气孔的发育。结果表明, 弱光环 境下生长的葡萄幼苗, 叶片的水势较高, 但水分利用效率较低, 叶片蒸腾速率和气孔导度变化对光照强度的响应缓 慢, 而自然光下生长的葡萄叶片则反应较迅速。通过对气孔结构的研究发现, 与自然光照环境下生长的植株相比, 在弱光环境下生长的葡萄幼苗, 叶片下表皮的气孔横轴变宽, 大小气孔之间差异减少, 气孔外突, 表皮细胞变大甚 至扭曲, 角质层变薄。说明葡萄幼苗能够对弱光环境产生适应性变化, 其蒸腾特性的变化与其气孔结构的变化相 关, 具有一致性。
\end{abstract}

关键词 弱光 水分利用效率 蒸腾速率 气孔

\section{LEAF TRANSPIRATION AND STOMATAL STRUCTURE OF YOUNG GRAPE PLANTS GROWN IN A LOW LIGHT ENVIRONMENT}

\author{
ZHAN Ji-Cheng HUANG Wei-Dong ${ }^{*}$ WANG Xiu-Qin and WANG Li-Jun \\ (College of Food Science and Nutritional Eengineering, China Agricultural University, Beijing 100094, China)
}

\begin{abstract}
Plant adaptation to its growing environment is reflected in physiological responses, such as stomatal conductance, photosynthetic rate, transpiration rates, and water use efficiency. We studied the influence of low light levels on leaf transpiration rate and stomal structure of young 'Jingyu' grape plants, Vitis vinefera L. cv. Jingyu, grown for 30 days under different light intensities (65\% shading and $85 \%$ shading). The transpiration rate, stomatal conductance, and water use efficiency were measured using a portable photosynthesis system, and the stomata were observed using a scanning electron microscope. The results showed that the leaf water potential of young grape plants grown under a low light environment was higher but water use efficiency was lower as compared to the controls. Transpiration rate and stomatal conductance responded slowly to varied light intensities, whereas the young grape plants grown under natural light environment were more sensitive to changing light intensities. For the young grape plants grown under low light environment, the horizontal axes of their stomata were broaden and the difference between "larger" and "smaller" stomata was reduced. The stomata protruded out of the epidermal wall and even distorted the cuticle of the epidermal surface. Our results showed that young grape plants were able to adapt to a low light environment, and their leaf transpiration characteristics were correlated with stomatal structure.
\end{abstract}

Key words Low light, Water use efficiency, Transpiration rate, Stomata

气孔是叶片蒸腾及光合原料 $\mathrm{CO}_{2}$ 进入细胞内的 通道, 其行为与植物叶片的蒸腾和光合性能有着密 切的关系 (Farquhar \& Sharkey, 1982; 许大全等, 1987; 许大全, 1995)。组成气孔的保卫细胞对环境条件非 常敏感, 可以通过气孔开放来调节水分的出入 (孟凡 霞等, 2000)。植物调节气孔开放的能力使之能够调
节蒸腾的速度, 以适应其水分平衡的需要。

气孔导度、水分利用效率等生理生态学指标对 光照环境的响应作为植物水分生理生态学的重要研 究内容, 前人已经有过不少研究成果 (Cowan, 1977; Yu \& Wang, 1998), 但在气孔结构变化对光照环境 的响应缺少相关报道。气孔功能是有其结构基础 
的,如保卫细胞壁角质层的特化 (Appleby \& Davies, 1983 )等。除某些没有叶绿素的植物如水晶兰属 ( Monotropa) 和鸟巢兰属 (Neottia) ( Willmer \& Fricker, 1996), 气孔普遍存在于植物的叶片表皮上, 象葡萄 (Vitis)等多数植物的叶片下表面气孔多于上表面, 这使植物不易受到伤害并更能适应干旱环境。气孔 结构的形成和发育则与基因型和环境条件有关。弱 光环境下, 植物的生长、形态及光合特性等都发生了 适应性变化(黄卫东等, 2002; Zhan et al., 2002; 战吉 成和黄卫东, 2002; 战吉成, 2002)。但是, 生长在弱 光下的植物, 其叶片蒸腾对光环境的适应性变化与 其气孔结构和行为的变化之间存在何种关联引起了 我们的兴趣。

随着中国设施农业的快速发展, 弱光环境的影 响越来越突出。本试验选取设施葡萄栽培中常用的 “京玉'葡萄( Vitis vinefera cv. Jingyu) 为试验材料, 观 察和分析了在弱光下生长的葡萄叶片蒸腾特性和气 孔结构变化之间的关系。

\section{1 材料和方法}

\section{1 材料和处理}

试验于 $2000 \sim 2002$ 年在中国农业大学进行, 试 验材料种植为 2000 年 4 月 2001 年 11 月和 2001 年 4 月～ 2001 年 11 月, 试验材料为一年生 “京玉”葡萄 无性繁殖扦插苗。当幼苗长到 $2 \sim 3$ 片叶时, 选择生 长健壮、粗度及大小一致的扦插苗盆栽, 黑色塑料盆 规格 $16 \mathrm{~cm} \times 20 \mathrm{~cm}$, 土壤配比为腐殖土: 园土: 蛭石 $=1: 1: 1$, 并进行两种不同程度的遮光处理。试验共 设 1 个对照, 2 个处理: 无遮阳网为对照 (CK); 1 层 黑色遮阳网, 光强约为自然光的 $35 \%$, 相当于遮光 $65 \% ; 2$ 层黑色遮阳网, 光强约为自然光的 $15 \%$, 相 当于遮光 $85 \%$ 。供试植株为 144 株, 每处理 16 株, 3 次重复, 随机区组排列。遮阳网放在离地面 $1.2 \mathrm{~m}$ 的木框架上, 持续处理时间 $30 \mathrm{~d}$ 。

不同处理的光温环境 (用光合有效辐射计、温度 计等测定)日变化示例见图 1 。弱光环境与自然环 境之间的差别以光照强度最为显著。

\section{2 方 法}

当遮光处理 $30 \mathrm{~d}$ 后, 每个重复选取 3 株葡萄 苗, 于上午 9:00, 取相同节位 (倒数第五片) 的已发 育成熟的叶片, 测试各个指标 (3 次, 取平均值)。

同时取不同处理的葡萄叶片进行水势测定, 水 势用压力势法测定 (中国科学院上海植物生理研究 所, 1999)。
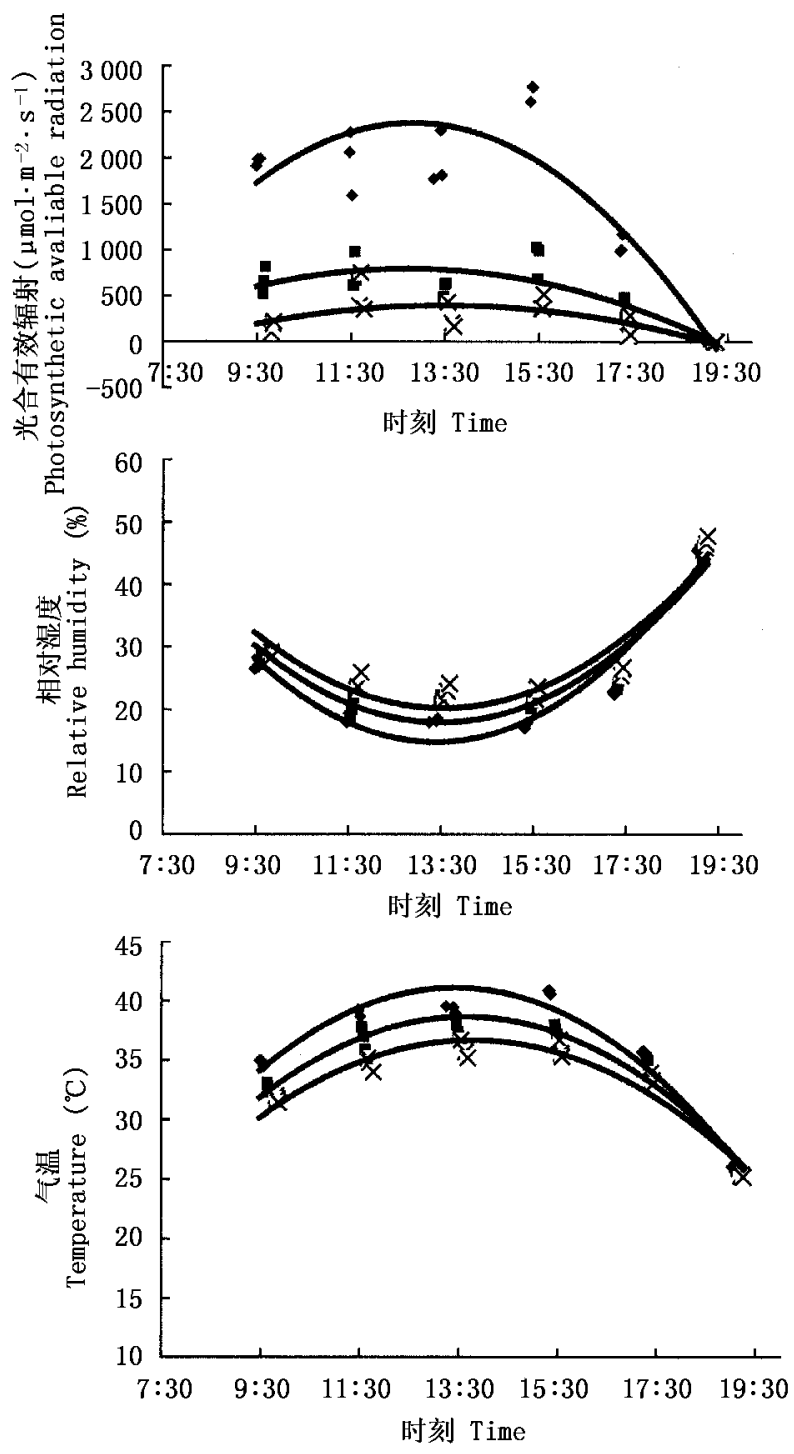

- 对照CK 日遮光65\% 65\% Shading $\times$ 遮光 $85 \%$ 85\% Shading

图 1 不同处理的光温环境

Fig.1 The different growing environment of young 'Jingyu' grape plants

用英国 PP-Systems 公司生产的 CIRAS-1 便携式 光合测定系统测定叶片的瞬时净光合速率 $P_{n}$ 和蒸 腾速率 $T_{r}$, 气孔导度 $G_{s}$, 按公式 $W U E=P_{n} / T_{r}$ 或 $W U E=P_{n} / G_{s}$ 计算单叶水分利用效率, 绘制光-水分 利用效率曲线; 同时利用所获得的气孔导度和蒸腾 速率的参数绘制光-气孔导度和光-蒸腾速率响应曲 线。

气孔观察: 由于葡萄的气孔主要分布于叶片的 下表面及叶片边缘, 试验主要对叶片下表面的气孔 进行了扫描电镜观察, 同时也对叶片上表皮细胞的 形状、大小及角质层的发育情况进行了观察。从不 同处理的相同节位的叶片上, 取 $2 \mathrm{~mm} \times 2 \mathrm{~mm}$ 大小 的叶块置于 $2.5 \%$ 的戊二醛中固定, 经乙醇系列梯 度脱水、临界点干燥、粘台喷金后在扫描电镜下观察 
20 30 个视野照相, 观察表皮细胞形态、角质层发 育情况, 测量气孔开张度和大小。

\section{2 结果与分析}

\section{1 弱光环境下生长的葡萄幼苗的叶片水势}

图 2 表明, 与在自然光环境中生长的葡萄植株 相比, 弱光环境下生长的葡萄幼苗叶片的水势较高 (上午 9:00)。这表明弱光环境下生长的葡萄幼苗 叶片蒸腾失水较少, 即叶片蒸腾与根系吸水速率之 间差异较少。

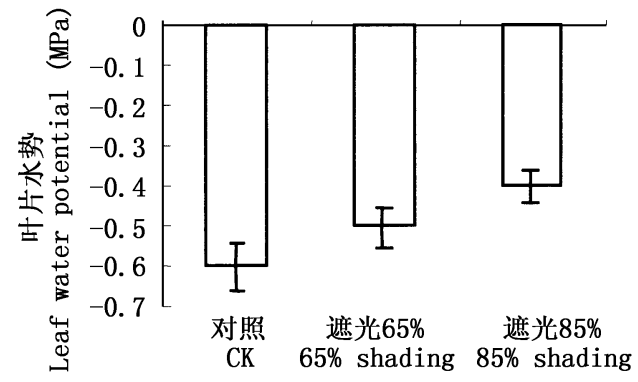

图 2 弱光环境下生长的葡萄幼苗的叶片水势

Fig.2 The leaf water potential of young 'Jingyu' grape plants grown under low light intensity

2.2 弱光环境下生长的葡萄幼苗叶片蒸腾速率、水 分利用效率和气孔导度对光强的响应

\subsection{1 叶片蒸腾速率}

图 3 表明, 在一定的光照条件下 ( $<1000 \mu \mathrm{mol}$ ・ $\left.\mathrm{m}^{-2} \cdot \mathrm{s}^{-1}\right)$, 弱光环境, 尤其遮光 $85 \%$ 环境中生长的 葡萄幼苗, 叶片蒸腾速率要比自然光环境中生长的 葡萄幼苗高; 但是, 随着光照强度的增加, 自然光环 境下生长的葡萄幼苗, 其叶片的蒸腾速率迅速增加, 达到最高点后, 迅速下降, 而弱光环境下生长的, 其 蒸腾速率的上升和下降则比较平缓。

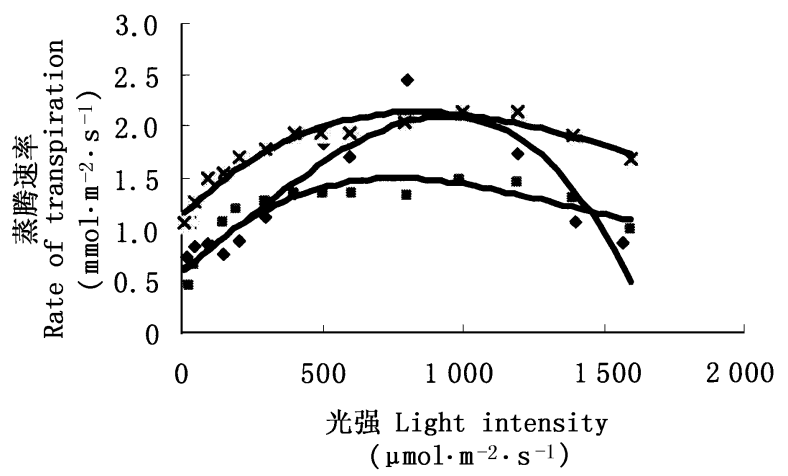

图 3 弱光环境下生长的葡萄幼苗叶片的蒸腾速率-光强曲线 Fig.3 Response curve of leaf transpiration rate to light intensity of young 'Jingyu' grape plants grown under low light environment ↔、x : 同图 1 See Fig. 1

\subsection{2 叶片水分利用效率}

单叶水分利用效率, 又称为瞬时水分利用效率, 可用单叶净光合速率 $P_{n}$ 和蒸腾速率 $T_{r}$ 之比 $P_{n} / T_{r}$ 表示, 也可用单叶净光合速率 $P_{n}$ 与气孔水蒸气导 度 $G_{s}$ 之比 $P_{n} / G_{s}$ ( 内在水分利用效率) 表示 (中国科 学院上海植物生理研究所, 1999)。它们可以反映测 定时植物的水分利用性能。

图 4 表明, 在弱光照下 $\left(<400 \mu \mathrm{mol} \cdot \mathrm{m}^{-2} \cdot \mathrm{s}^{-1}\right)$, 不同光环境下生长的葡萄幼苗, 叶片的水分利用效 率都随光强的增加而增加, 但弱光环境下生长的葡 萄幼苗要明显低于自然光下生长的。随着光强的继 续增加, 弱光环境下生长的葡萄幼苗, 水分利用效率 略微下降而后呈缓慢上升状态, 而自然光下生长的, 叶片的水分利用效率下降和上升的幅度较大。

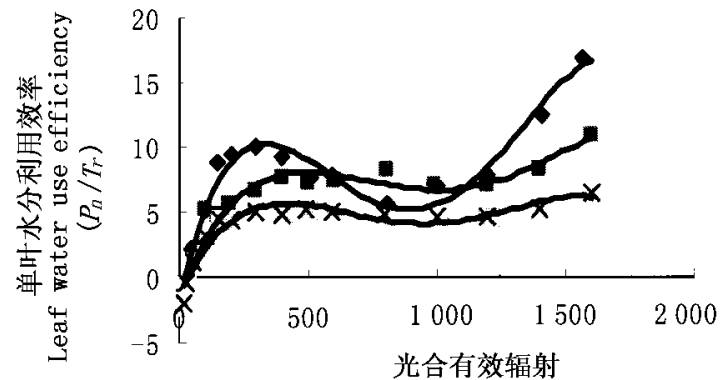

Photosynthetic avaliable radiation $\left(\mu \mathrm{mol} \cdot \mathbf{m}^{-2} \cdot \mathrm{s}^{-1}\right)$

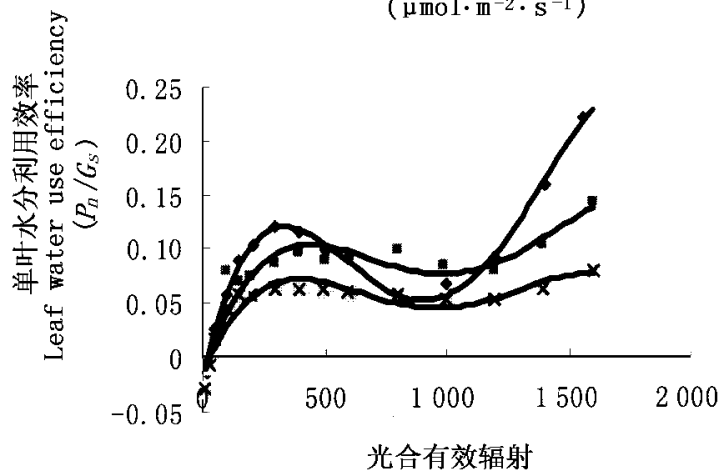

Photosynthetic avaliable radiation $\left(\mu \mathrm{mol} \cdot \mathrm{m}^{-2} \cdot \mathrm{s}^{-1}\right)$

图 4 在弱光环境下生长的葡萄幼苗叶片的水分利用效率-光强曲线 Fig.4 Response curve of leaf water use efficiency to light intensity of young 'Jingyu' grape plants grown under low light environment ๑、、x : 同图 1 See Fig. 1

\subsection{3 叶片气孔导度}

图 5 表明, 弱光环境下生长的葡萄叶片, 叶片气 孔导度对光强的响应比较平缓, 而且, 气孔导度的变 化趋势与蒸腾速率的变化趋势相似。相反, 自然光 下生长的葡萄叶片气孔导度对光强的响应比较剧 烈, 变动幅度较大。 
2.3 弱光对 “京玉”葡萄幼苗叶片下表皮气孔形态 特征的影响

用扫描电镜下观察各处理叶片表皮气孔形态， 可以看到: 对照(图 6G) 叶片下表皮存在典型的由大 气孔及其周围体形较小的气孔形成的气孔群, 除大 气孔外突明显外, 小气孔多与表皮平齐或下陷(图 $6 \mathrm{~A})$; 遮光 $85 \%$ 处理的叶片下表皮气孔无论大小多 突出表皮(图 6C)。将各处理的大气孔放大, 并旋转 角度可以观察到对照叶片下表皮的气孔周围褶䏢多 且深(图 6D)。而弱光处理的气孔基本上突出于表 皮细胞之上, 周围虽有高低起伏的角质层, 但角质层 之间没有褶皱叠错( 图 6E、F)。

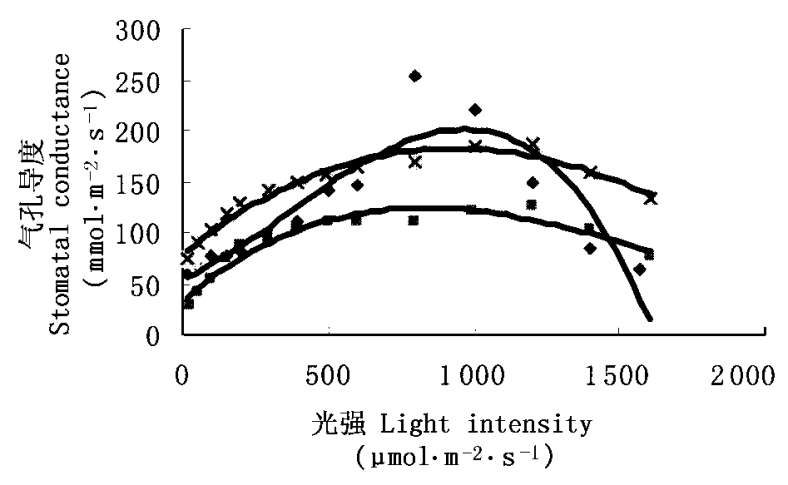

图 5 在弱光环境下生长的葡萄幼苗叶片的气孔导度-光强曲线

Fig.5 Response curve of leaf stomatal conductance to light intensity of young 'Jingyu' grape plants grown under low light environment

↔、、x : 同图 1 See Fig.1

2.4 弱光对京玉葡萄幼苗叶片上表皮细胞形态、大 小和角质层发育的影响

自然光环境下生长的叶片, 上表皮细胞较小, 呈 圆形, 表皮细胞的角质层发达 (图 $6 \mathrm{~J}$ ); 遮光 $65 \%$ 环 境中生长的叶片的上表皮细胞较大, 外表面较平整,
呈方形 (图 6K); 遮光 $85 \%$ 环境中生长的叶片的上表 皮细胞形状不规则, 相互镶嵌。角质层是植物叶表 面由角质和蜡质组成的膜状结构, 并由果胶层连结, 覆盖在表皮细胞外表面的细胞壁上, 对植物起着机 械防护和失水防护的作用。从扫描电镜里可以明显 看到, 弱光环境下生长的葡萄叶片, 上表面角质层发 育不完善, 角质层呈条纹状 (图 6L)。

\section{3 讨 论}

\section{1 弱光生境对葡萄蒸腾特性的影响}

植物的水势与植物体叶片蒸腾强度与根系吸水 速率之间的差异有关, 差别越大, 叶片水势越低, 尤 其是蒸腾总量越大, 可能导致叶片水势更低。弱光 环境下生长的葡萄叶片水势高 (图 2), 则表明其蒸 腾与根系吸水速率之间差异要少于自然光下生长的 葡萄。由于弱光环境下生长的葡萄根系数量减少 (战吉成和黄卫东, 2002), 可以推测弱光下生长的葡 萄幼苗蒸腾总量要明显低于自然光下生长的葡萄幼 苗。

从图 3 和图 5 来看, 弱光环境下生长的葡萄叶 片, 其叶片蒸腾速率和气孔导度对光强的响应比较 平缓, 气孔导度的变化趋势与蒸腾速率的变化趋势 相似。而自然光下生长的葡萄叶片气孔导度对光强 的响应比较剧烈, 变动幅度较大。该结果表明自然 光下生长的葡萄叶片气孔对光强的响应比弱光下生 长的葡萄叶片上的气孔灵敏。

Cowan( 1977) 很早就提出, 气孔的开放不仅是为 防止植物过度失水, 而且可以使植物水分利用效率 最大化。在相同光照条件下, 弱光环境下生长的葡 萄幼苗水分利用效率较低 (图4)。而且弱光环境下

图 6 扫描电镜下观察到的各处理叶片表皮气孔形态

Fig.6 Stomatal shape of epidermal surface in leaves under different light environment scanned by electron microscope

A. 对照放大的下陷小气孔 $(\times 2000)$ B. 遮光 $65 \%$ 处理放大的下陷小气孔 $(\times 2000) \quad$ C. 遮光 $85 \%$ 处理放大的外突小气孔 $(\times 2000)$ D. 对照放大的大气孔 $(\times 2000)$ E. 遮光 $65 \%$ 处理放大的大气孔 $(\times 2000)$ F. 遮光 $85 \%$ 处理放大的大气孔 $(\times 2000) \quad G$. 对照植株叶片下 表皮扫描电镜照片, 可见典型的由大气孔和周围辐射状排列的小气孔组成的气孔群 $(\times 200)$ H. 遮光 $65 \%$ 处理植株叶片下表皮扫描电镜照片 （ $\times 200 ）$ I. 遮光 $85 \%$ 处理植株叶片下表皮扫描电镜照片 $(\times 200)$ J. 对照上表皮细胞的形状和排列 $\mathrm{K}$. 遮光 $65 \%$ 处理上表皮细胞的形状 和排列 L. 遮光 $85 \%$ 处理上表皮细胞的形状和排列 A. Showing enlarged “smaller” stomata of the controls, which were a little lower compared with adjacent epidermal cells $(\times 2000)$ B. Showing enlarged “smaller” stomata of $65 \%$ shading treatment $(\times 2000)$ C. Showing enlarged “smaller” stomata of $85 \%$ shading treatment, which were protruded above the adjacent epidermal cells $(\times 2000) \quad$ D. Showing enlarged "larger" stomata of the controls $(\times 2000)$

E. Showing enlarged "larger" stomata of $65 \%$ shading treatment $(\times 2000) \quad$ F. Showing enlarged "larger" stomata of $85 \%$ shading treatment $(\times 2000)$ G. Scanning electron microscope picture of lower epidermal surfaces in leaves of the controls, showing higher stomata density and typical stomata clusters which were consisted of the central "larger" stomata and "smaller" satellite stomata ( × 200) H. Scanning electron microscope picture of lower epidermal surfaces in leaves of $65 \%$ shading treatment, showing increased stomata aperture $(\times 200) \quad$ I. Scanning electron microscope picture of lower epidermal surfaces in leaves of $85 \%$ shading treatment, showing increased stomata aperture, most stomata were protruded above the epidermal level $(\times 200)$ J. Showing the shape and arrangement of upper epidermal surface in leaves of the controls K. Showing the shape and arrangement of upper epidermal surface in leaves of $65 \%$ shading treatment

L. Showing the shape and arrangement of upper epidermal surface in leaves of $85 \%$ shading treatment 
CK

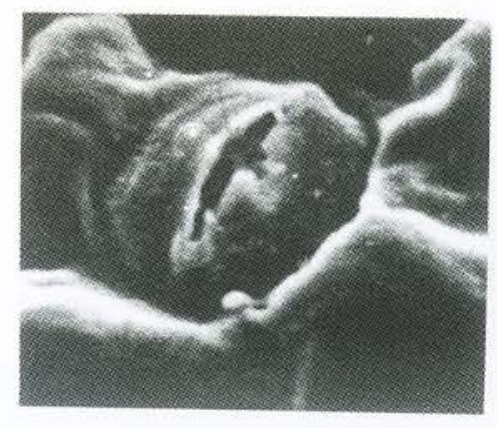

A

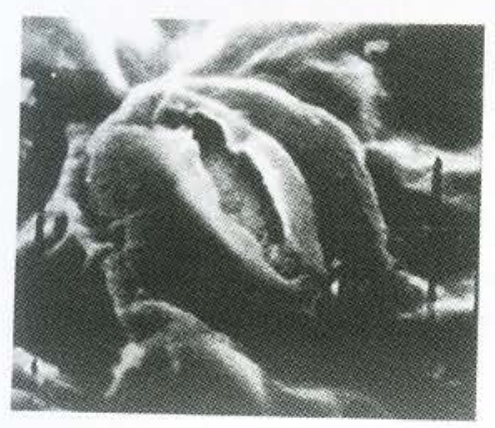

D

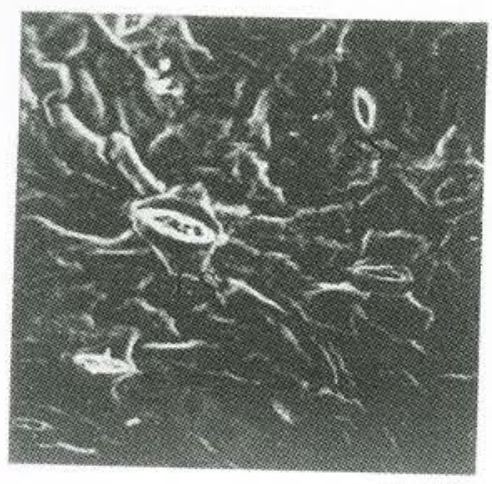

G

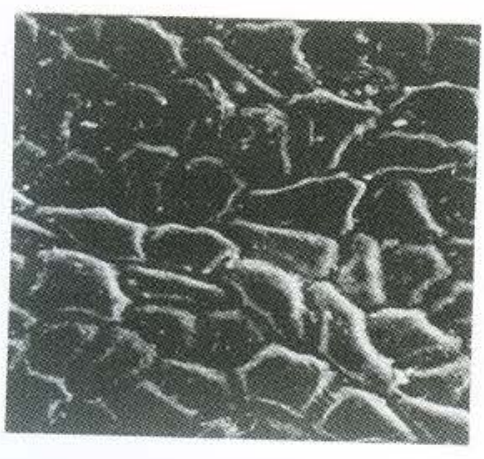

$65 \%$ Shading

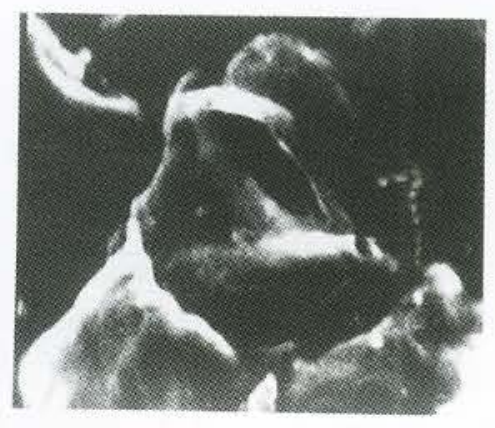

B

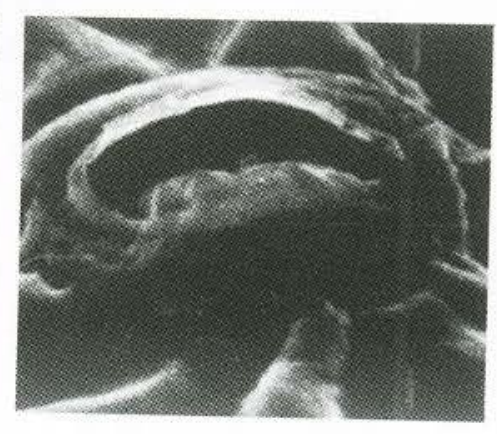

E

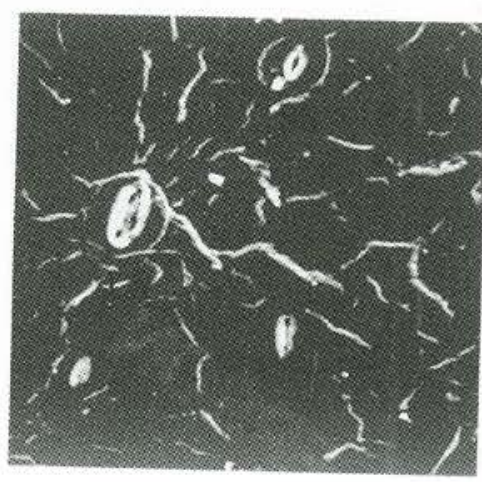

H

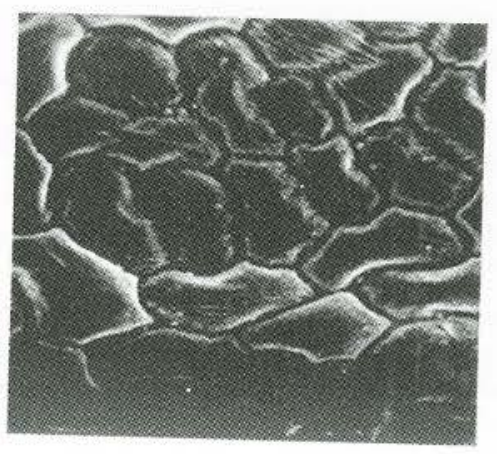

85\% Shading

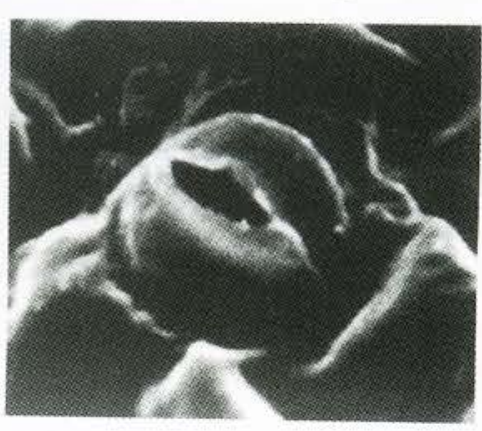

C

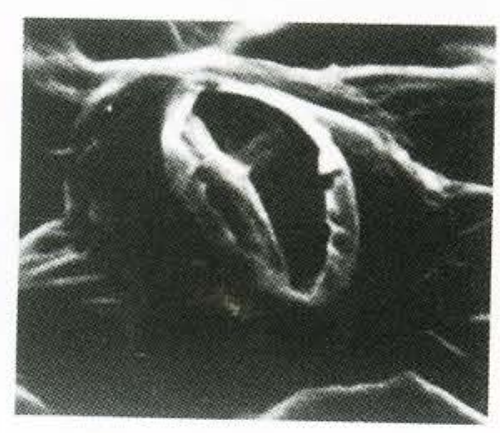

F

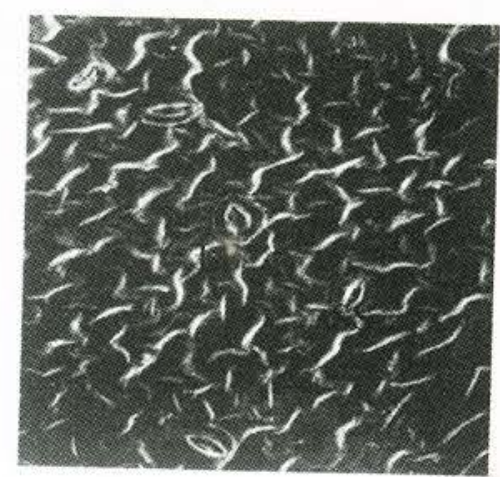

I

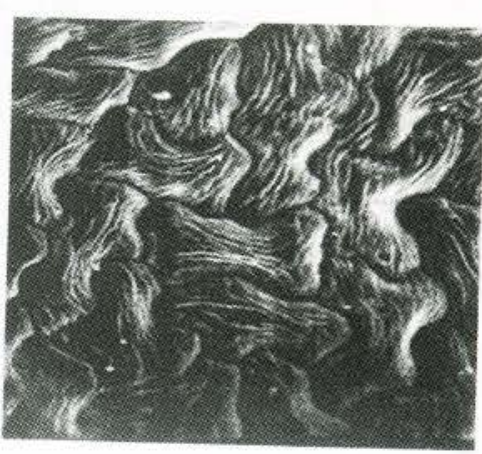


生长的葡萄幼苗, 其叶片气孔对光照的响应较迟针, 水分利用效率随光照强度的变化较慢。至于图 4 中 一段下降趋势应是叶片光合效率随光合有效辐射增 加上升缓慢, 而蒸腾量呈直线上升, 大于 $1000 \mu \mathrm{mol} \cdot$ $\mathrm{m}^{-2} \cdot \mathrm{s}^{-1}$ 以后, 气孔关闭导致蒸腾量急剧降低, 而光 合下降要慢于蒸腾所致。

\section{2 弱光生境对葡萄叶片气孔结构的影响}

气孔的启闭运动是植物适应环境变化的一种主 动调节, 其功能依赖于其结构基础。一个气孔可能 开放的程度取决于保卫细胞的形状和细胞壁的性 质。而弱光环境下生长的葡萄幼苗, 叶片下表皮气 孔的横轴相对加宽 (图 6D、E、F), 既不利于气孔的迅 速开放和关闭, 也减少了气孔可能开放的最大程度 和最小程度之间的差距, 因而对外界反应的敏感性 减弱。而自然光下生长的葡萄幼苗, 其叶片的气孔 导度和蒸腾速率对光强的变化比较敏感 (图 3, 图 5 ), 则可能与其气孔的狭长结构有一定的关系。

气孔突出表皮有利于水分散失, 下陷气孔则有 利于保持水分。不同形态气孔的存在增加了葡萄对 环境条件的适应能力。弱光环境下生长的葡萄幼 苗, 其叶片气孔外突及角质层变薄的结果表明, 由于 蒸腾总量较少, 弱光条件下发育的葡萄叶片, 已经不 需要通过厚厚的角质层和深陷的气孔来防止水分散 失。

植物的形态结构和生理机能对环境的适应性, 使植物能最有效地利用环境资源, 从而趋于最佳生 长状态 (陈德兴和王天铎, 1990)。因此, 弱光环境下 生长的葡萄幼苗叶片的气孔结构和蒸腾特性的变化 可以认为是一种环境适应的结果。不过, 这种适应 性变化有时可能会变成不利因素, 即在温度和光照 较高时,产生适应性变化的叶子很容易失水萎蒸。 在生产上, 人们经常发现将温室培育的苗木直接移 放到自然强光下, 苗木很容易发生萎蒸, 便可能与此 有关。$$
\text { 参 考 文 献 }
$$

Appleby RF, Davies WJ (1983). The structure and orientation of guard cells in plants showing stomatal response to changing vapour pressure difference. Annals of Botany, 52, 459-468.

Chen DX (陈德兴), Wang TD (王天铎) (1990). Adaptation of leaf mesophyll structure to environmental light condition and its effect on leaf photosynthesis. Chinese Journal of Applied Ecology (应用生态学报), 1, 142 - 148. (in Chinese with English abstract)

Cowan IR(1977). Stomatal behavior and environment. Advances of Botany Research, 4, $117-228$.

Farquhar GD, Sharkey TD(1982). Stomatal conductance and photosynthesis. Annual Review of Plant Physiology and Plant Molecular Biology, 33, 317 - 345 .

Huang WD (黄卫东), Wu LK (吴兰坤), Zhan JC (战吉成) (2002). Effect of weak light on the peroxidation of membrane lipid of cherry leaves. Acta Botanica Sinica (植物学报), 44, 920 - 924. (in Chinese with English abstract)

Shanghai Institute of Plant Physiology, the Chinese Academy of Sciences(中国科学院上海植物生理研究所) (1999). Guide of Plant Physiology Experiment (现代植物生理学实验指南). Science Press, Beijing. (in Chinese)

Meng FX(孟凡霞), Zhang SQ (张蜀秋), Lou CH (娄成后) (2000). The structural foundation of stomatal function. Chinese Bulletin of Botany (植物学通报), 17, 27 - 33. (in Chinese with English abstract)

Thomson WW, Dejournett R(1970). Studies on the ulstructure of guard cells of Opunitia. American Journal of Botany, 57, 309 316.

Willmer C, Fricker M(1996). Stomata. Chapman \& Hall, London.

Xu DQ(许大全), Li DY(李得耀), Qiu GX(邱国雄), Shen YG (沈允钢) (1987). Stomatal limitation of photosynthesis in the bamboo (Phyllostachys pubescens) leaf. Acta Phytophysiologica Sinica (植物生理学报), 13,154-160. (in Chinese with English abstract)

Xu DQ(许大全) (1995). Non-uniform stomatal closure and non stomatal limitation of photosynthesis. Plant Physiology Communications (植物生理学通讯), 31, 246-252. (in Chines)

Yu Q, Wang TD (1998). Simulation of the physiological responses of $\mathrm{C}_{3}$ plant leaves to environmental factors by a model which combines stomatal conductance, photosynthesis and transpiration. Acta Botanica Sinica (植物学报), 40, 740-754.

Zhan JC, Huang WD, Wang LJ(2002). Effect of weak light on the photoassimilates distribution and transformation of young grape plants. Agricultural Sciences in China, 1, 1006 - 1011 .

Zhan JC(战吉成), Huang WD (黄卫东) (2002). Morphological and growth response of young grape plants to low light environment. China Agricultural Bulletin(中国农学通报), 18(2), 1 - 3. (in Chinese with English abstract)

Zhan JC(战吉成), Wang LJ (王利军), Huang WD(黄卫东) (2002). Effects of low light environment on the growth and photosynthetic characteristics of grape leaves. Journal of China Agricultural University (中国农业大学学报), 7(3), 74-78. (in Chinese with English abstract) 